\title{
Legal System of Corporate Management in Nepal
}

\section{Suman Acharya, PhD}

\author{
Email: sumanacharaya@gmail.com
}

\begin{abstract}
s
Company, an association of people, has been established to carry out specific goals under law. The contemporary development of human world is possible only through the incorporation of the people to accomplish specific goals. It has specific organic structures i.e. Board of Directors, Management Committee, Audit Committee, other Committees etc. The meeting of Board of Director has to record in a minute, which is enforceable through the body of the company. Decision making process is unanimous; otherwise, there can be voting for decision and dissent opinion has also been recorded in the minutes. The function of Board of Directors should be endorsed by the Annual General Meeting or Special General Meeting. Annual meeting requires attendance with prescribed quorum and financial statements. The financial health is examined by internal and external auditors. The qualified opinion of auditors require to correct with due care. In Nepal, Office of the Company Registrar and regulator like Nepal Rastra Bank regulates the Company under their jurisdiction. The provision of the Companies Act and other specialized laws are necessary to pursue. General meeting controls and regulates Board of Directors and Board regulates and control management committee. Management Committee controls and regulates employee and daily expenditures of the company. There should be effective control system in the company with separation of power, rule of law and check and balance.
\end{abstract}

\section{Introduction}

Company is the corporate veil of natural person formed to perform certain task under prevailing laws. Contemporary progress of human domain is possible only through the 
existence of the company. ${ }^{1}$ It has both individual and social role. On the one hand company seeks profit and on the other hand it performs work in congregation of the natural persons with shared bond. Company may be incorporated either singly or collectively. ${ }^{2}$ The application for the registration of the company should be submitted online in the Office of the Company Registrar including Memorandum of Association; ${ }^{3}$ Articles of Association; ${ }^{4}$ a copy of an agreement made between promotes prior to the incorporation of the company for public company, a copy of consensus agreement for private company, prior approval or license from any authority to carry on some specific business or transactions according to prevailing laws of the country if so, a copy of such approval or license; a certified copy of citizenship certificate and if the promoter is a corporate body of directors and major incorporation, decision of the board of directors and major incorporation documents. ${ }^{5}$ Office of the Company Registrar may refuse to register the company if it is contrary to prevailing companies name, trademark, national integrity, sovereignty, public morals and order and creating illusion to liquidated company. ${ }^{6}$

\section{Applicable laws}

Nepal has Companies Act, 2063 BS (2006 AD), which primarily regulates company system in Nepal. ${ }^{7}$ Additionally, there are other regulatory laws like Nepal Rastra Bank Act, 2058 BS (2002 AD), Banks and Financial Institutions Act, 2073 BS (2017 AD), Securities Act, 2063 BS (2007 AD), Insurance Act, 2049 BS (1992 AD) etc. Once the

\footnotetext{
1 Vide Janet Dine. Company Law. 1 ( $4^{\text {th }}$ ed. 2001). Palgrave.

2 Companies Act $\S$ Sec.3(1) (2063). http://www.lawcommission.gov.np/np/wpcontent/uploads/2019/04/17.\%E0\%A4\%95\%E0\%A4\%AE\%E0\%A5\%8D\%E0\%A4\%AA\%E0\%A4\%A8\%E0\%A5\%80-\%E0\%A4\%90\%E0\%A4\%A8\%E0\%A5\%A8\%E0\%A5\%A6\%E0\%A5\%AC\%E0\%A5\%A9.pdf. (Last Visited 5/27/2020).

$3 \quad$ Id. § Sec. 18.

$4 \quad$ Id. $\S$ Sec. 20.

$5 \quad$ Id. $\S$ Sec. 4.

$6 \quad$ Id. $\S$ Sec. 6.

7 Prior than current legislation, there was Nepal Company Act, 1993 BS, Nepal Company Act, 2007 BS, Company Act, 2021 and Company Act 2053 BS. Current Companies Act, 2063 has replaced the Company Act, 2053 BS.
} 
approval received from such regulators, the company can be registered in the Office of the Company Registrar in Nepal. If anything has not been incompatible with specialized laws, the provision of the Companies Act is applicable in Nepal. In addition to national legislation, internal constitution like Memorandum of Association, Articles of Association, Prospectus and Financial Statement play important role in the operation of the Company. Compatibility in all these documents has been expected.

\section{Types of Companies}

Company law of Nepal has prescribed public, private, foreign and not for profit companies. It has equally listed or unlisted as well as principal and subsidiary companies. It is based on the nature of holding and profit making status.

- Private Limited Company: It can be single or of more than one shareholder. A private company incorporated by a single person is called single shareholder company. In relevance to the company, number of promotes are 1-50 in private limited company.

- Public Limited Company: Public Company requires at least 7 shareholders. It has the involvement of the general people.

- Non Profit Company: The Company which is not for profit can be established. It cannot distribute bonus and dividend for shareholders. There will be no certificate of shareholder for the company of not for profit. Their role is to act as a social service company.

- Foreign Company: It can be joint venture or fully funded company in Nepal. It has to be registered in the Office of the Company Registrar.

- Listed and Unlisted Companies: It is based on the listing in NEPSE. Generally, public limited companies are listed there and there is no compulsory provision for private companies although it is allowed by many foreign countries. 
- Chartered Company: Such company has been established with the charter of the head of the State. It had been practiced well during colonization period i.e. East India Company.

- Statutory Company: These companies are established under special law of the country. Australia and the UK have better practices of it.

- Holding and Subsidiary Company: Holding company refers to principal company and subsidiary company is controlled by the holding company. Holding company maintains its control by majority of shares, direct or indirect control over the formation of the Board of Directors.

- Government Company: It is established by the government with full or partial contributions. If government gets the share above than fifty percent it comes under Government Company.

- Unlimited Company: Under these types of company, there are unlimited liabilities of the members of the company. It may also personal liability as well.

\section{Doctrine of the Company}

Company is established under law and operated under same fashion. There are numbers of principles have been emerged gradually over the period of time across the globe. Some of the principles are as under.

- Doctrine of Ultra Vires: Company is established under certain objectives mentioned in its memorandum. In fact, the objectives and organic structures of the company are mentioned in Article of Association and Memorandum of Association. Company must follow proper authority. It protects investor and creditors in the company. ${ }^{8}$

- Doctrine of Lifting the Corporate Veil: Company is ultimately operated by the natural persons. If any civil and criminal wrong occur in the company, it is

$8 \quad$ Vide Janet Dine. Company Law. 46 ( $4^{\text {th }}$ ed. 2001). Palgrave. 
necessary to determine the wrong-doing person. So, doctrine of lifting the corporate veil is important principles in incorporated body. ${ }^{9}$

- Doctrine of Constructive Notice: A person dealing with the company is expected to know the Memorandum of Association and the Articles of Association including other public records of the company that are submitted to the Office of the Company Registrar in the context of Nepal. Yet, outsiders not permissible by the constituent documents have no any rights to get access in such documents. ${ }^{10}$

- Doctrine of Indoor Management: It is the exceptions rules of the doctrine of constructive notice. It is expected that the procedure and internal regularities are maintained in the company. If there are the presences of internal irregularities and procedural requirements, outsider having concern can get the information of the company as a remedy of it. ${ }^{11}$

- Doctrine of Fraud: Company can be powerful vehicle for the fraudulent people although it is against prevailing laws. All the principles of the company blurred in case of the fraudulent use of the company. It discourages fraud schemes. It has been interpreted by English Court in Solomon's Case.

\section{Organic Structures}

Company is not only the congregation of natural person but also the part of corporate legal system emanating from regulators to shareholders. The basic organic structures of the companies are as under.

- Officials of the Company Registrar and Other Regulators: Office of the Company Registrar is the primary regulators of the company in Nepal. Each and every country has their own structure for the purpose of the regulation of the company. For the purpose public limited companies, there are specialized regulators as prescribed i.e. Nepal Rastra Bank, the central bank, for Banks and

$\begin{array}{ll}9 & \text { Id. } 28-31 . \\ 10 & \text { Id. } 47 . \\ 11 & \text { Id. } 56 .\end{array}$


Financial Institutions. Companies have dual responsibility with specialized regulators if applicable and to the office of the Company Registrar. ${ }^{12}$

- Promoters Meeting: Prior than the establishment of the company, the group of promoters congregate together and decides for the establishment of the company in concerned authority. ${ }^{13}$ It forms Board of Directors for temporary purpose of the establishment of the company. They can make special agreement for the purpose of the establishment of the company but it shouldn't be illicit and illegitimate agreement.

- First Annual General Meeting: Each public company should hold first annual general meeting within one year from the date of receipt of the certificate of commencement of business from the office of the company registrar. And private company should hold meeting within the date mentioned in article of association. ${ }^{14}$

- Annual General Meeting: In case of public limited company, it has been conducted in the district having registered office whereas in case of the private limited company it can be conducted in any place of the country. Prior than 21 days of the annual general meeting, the notice with venue, date and time requires to issue. In case of resumption of postponed meeting, it needs only 7 days prior information to concerned shareholders. No decision can be done if at least 67 percent shareholder didn't make own or proxy present. Director should present himself or herself. If there is the genuine reason not to able to present in the meeting, the video conferencing is also acceptable. ${ }^{15}$

- Special General Meeting: If special decision is to be taken after annual general meeting or if there is long span of time unable to hold annual general meeting, shareholders or auditors may demand with board for the special general meeting. If the Board doesn't convene it, the application can be submitted to Office of the Company Registrar. Shareholders holding at least $10 \%$ of shares of the company

Companies Act § Sec. 16. (2063).

Id. § Sec. 17.

Id. § Sec.67.

Id. § Sec. 67. 
paid up capital or at least $25 \%$ of the total numbers of shareholders can request Office of the Company Registrar to hold special general meeting if board doesn't do it. ${ }^{16}$

- Quorum: It is as prescribed in Article of Association in case of private limited company. For public company, at least fifty percent more shareholders' representation with at least 3 of them has physical or proxy presence is necessary. If general meeting is postponed because of quorum issue with the notice of 7 days, shareholder representing at least 25 percent shareholder from among total allocation of share with at least 3 of them has physical or proxy presence is necessary. It is not necessary for public enterprises and the committee established under Development Committee Act and public company establishing another public company. ${ }^{17}$

- Board of Directors: In public company it ranges from 3 to 11 , which is as prescribed in the Article of the Association of the company. They are appointed from among the shareholders. There should be at least one director if otherwise not mentioned. The success or failure of the company depends on the performance of the directors. However, it shouldn't be more than 11. Tenure of office for public company shall be 4 years. The director plays the role of agent of the company working on behalf of it, trustee working for the benefit of the company and shareholders, managing partner involved in the affairs of the company, organic brain of the company. First director is appointed by the subscribers of the memorandum of association and article of association prior than Annual General Meeting. After it AGM has the responsibility to appoint the directors. In case of vacant post of the directors appointed by general meeting, the Board has responsibility to appoint director for remaining time. If any disqualification in legislation, resolution of general meeting, resignation, court decision on

Id. § Sec. 73. 
dishonesty or vested interest, black list cause the removal of the director. Mala fide intention, deadlock and incompetency are the reason for the removal of the director. As they have fiduciary duty, acting in good faith, due purpose, acting with authority, not use of unfettered discretion, avoidance of conflict of interest, due care and proper skill are necessary. There are certain limitation on issuing notice to shareholders to deposit the amount of the shares subscribed; to issue debentures; power to obtain loans other than debentures; to invest Company's reserves; to provide loans (not applicable to BFIs) etc. ${ }^{18}$

- Executive Director: There is the provision of appointment of managing director in company law. They play executive role or day to day function administrative role as well.

○ Non-executive Director: They do not perform day to day administrative role. They are only the policy maker of the company.

○ Independent Director: A person having specialized knowledge in given field should be appointed as independent director. If there is the board up to 7 , there must be one independent director and if there are more than 7 directors, there should be two independent directors in the public company. ${ }^{19}$

o Women Director: If there is women shareholder, at least one director should represent from women. It can executive, non-executive, independent or else. ${ }^{20}$

- Minute of Decision: Every decision of the company should be recorded in the registry with due signature. Anonymous decision is expected but once it is impossible there can be the majority decision and note of dissent. The notice of meeting should be given to each member with place and address of the meeting. ${ }^{21}$
Id. § Sec. $86,87 \& 88$.
Id. $\S$ Sec. 86 (3).
Id. § Sec. 86 (2).
Id. § Sec. $97 \& 98$. 
It has to be maintained in a separate book. The proceeding of the general meeting should be signed by the chairman of the company and the company secretary. ${ }^{22}$ The derails of discussed minutes should be sent to all shareholders within 30 days of holding general meeting or publish such details in national daily newspaper. The company should keep minute in registered office, any shareholder desires to inspect shall be allowed for inspection.

- Audit Committee: In public company, separate audit committee should be established. They have the role to make the arrangement of internal auditing. It can also assist external auditor to make independent analysis of financial statement in the company. Auditing has important role to make compliance of law and order as prescribed. It shows the effective control system of the company so that malfunction and misappropriation of fund may not be occurred. Financial statement prepared by the external auditors is necessary in the time of general meeting, annual information to the regulators and renewal process. Even in the operation of bank account and other representation of the company, financial statement is necessary. ${ }^{23}$

- Management Committee: It is led by Chief Executive Office (CEO) or managing Director. They should avoid any form of biasness while implementing policy decision. They have the role to make day to day functioning of the company effectively and efficiently. ${ }^{24}$

- Committees: Board of the company can establish committee and sub-committee as per necessity for effective functioning of the company or to make recommendation in policy decision.

- Company Secretary: The Company having at least NPR Ten Million paid up capital must appoint company secretary from among the person receiving
Id. § Sec. 75(1).
Id. § Sec. 164.
Id. § Sec. 96. 
professional certificate with at least two years of experiences or form the person having masters degree in the business related subject. ${ }^{25}$

- Shareholder and Fundamental Shareholder: Shareholders are the building block of the company. Yet, fundamental shareholders have special rights and obligations. A person having 5 percent more share are taken as fundamental shareholders. In case of the company having NPR 250 Million, a person having 1 percent and more share are taken as fundamental shareholder. Their rights and duties are specially prescribed because they are dominant in company's performances. ${ }^{26}$

- Prospectus: It is the booklet consisting of information relating to the profile and details of the information. In the time of share allotment and general meeting, prospectus is required. Based on the information of prospectus, shareholder and other stakeholders get information about the company. ${ }^{27}$

- Staffs: Employees are the hand and feet of the company. The day to day operation and functioning completely goes on the knowledge, skill and attitude of the staff towards the company. Company should focus on the enhancement of knowledge and skills of the staff as well so that they can be competent in the company.

\section{Case laws}

- Foss vs. Harbottle: It is important precedent developed by the English court. It establishes the absolute rights of company as claimant if any wrong has been taken place. It has also established derivative rights of minority shareholders. Prevention of oppression of minority shareholders and mismanagement of a company are established by the case as the exception of the absolute rights of the company. ${ }^{28}$ Injunction, damage and rectification are the remedy for coerce act of majority. The

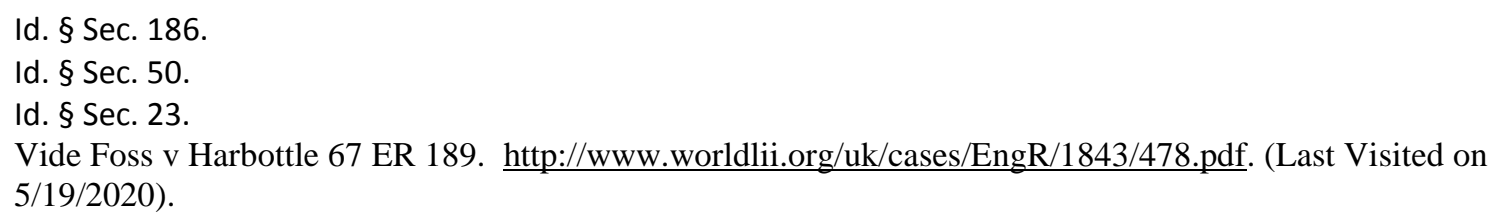


principle established by this case has been received by many country of the world in their company jurisprudence. These principles are incorporated in Nepalese Company Law as well.

- Unity Life International vs. Government of Nepal: It has been decided by the Supreme Court of Nepal. The lifting the corporate veil principle has been implemented by the Supreme Court of Nepal to determine the persons of the company involved in revenue leakage, tax evasion, personal use of property, illicit and deceitful act etc. ${ }^{29}$

\section{Conclusion}

Company has been established for multidimensional area in contemporary time. Every human development is possible only with the incorporation of the company. Nepal has good number of public, private, not-for-profit and foreign company. The presence of multinational company is growing and ever growing in Nepal. They are mobilizing the resources of Nepal and also accumulate foreign resources to make industrial product. It has Greenfield Sectors in many terms; both, national and international company can get much more benefit from here. Company has been operated with different organic body i.e. General Meeting, Board, Company Secretary, Management Committee, Committees, and Staff etc. Its power and functions are ultimately regulated and controlled by the Office of the Company Registrar and concerned regulators in case of public company.

'The End...' 